\title{
Development of the white-pink marshmallow formulas with using of "Magnetofood" food additive
}

\author{
Iryna Tsykhanovska ${ }^{1}$, Victoria Evlash ${ }^{2}$, Alexandr Alexandrov ${ }^{1}$, \\ TatyanaHontar ${ }^{1}$, Tetiana Lazareva $^{1}$, Olesia Nechuiviter ${ }^{1}$ \\ 1 - Ukrainian Engineering-Pedagogics Academy, Kharkiv, Ukraine \\ 2 - Kharkiv State University of Food Technology and Trade, Kharkiv, Ukraine
}

\begin{abstract}
It was investigated the effect of "Magnetofood" food additive in the powder form in the amount of $0,10 \% ; 0,15 \%$ and $0,20 \%$ by weight of the raw materials, on the process of structure formation of the gelling agent and foaming of the whipped mass in the whipped confectionery production as well as on the quality indicators of the finished product. It has been improved the marshmallow technology formulas of the white-pink marshmallow on agar and pectin. The formulations and technological schemes of the white-pink marshmallow on agar and pectin with "Magnetofood" additive in the amount of $0,15 \%$ by weight of raw materials were developed.
\end{abstract}

Corresponding author: Iryna Tsykhanovska

E-mail: cikhanovskaja@gmail.com

DOI: $10.24263 /$ RES-2018-8

\section{Introduction}

The confectionery industry is one of the active users of food additives and the improving agent in the products production. The use of food additives in the industry of whipped pastry, in particular marshmallow is due to a number of circumstances; the reasons and the directions of food additives using by the confectionery industry. The analysis of the information sources [1-32] shows the insufficiency of data on the marshmallow technologies with the using of nanopowder additives which have thickening, foam-and gelling, stabilizing capacities; improving the structural and mechanical properties of whipped masses and the quality indicators and the storagelife extender of marshmallows. As an additive - improving agent for food systems we have developed and proposed the "Magnetofood" food additive [TA Ter Admin/U 10.8-2023017824-001:2018]. It is the ultra-fine powder with a large specific and highly active surface.

In the food systems "Magnetofood" exhibits antioxidant, sorption, bacteriostatic, complexing, emulsifying, moisture-containing fat-containing, water-binding, stabilizing, structure-forming properties [1-4]. In this regard, it is relevant to improve the formulation and the existing technology of the white-pink marshmallow with the introduction to the formulating composition of "Magnetofood" food additive. 


\section{Results and discussion}

The study object is the technology of the white-pink marshmallow on agar and pectin. The research subject is the marshmallow model samples on agar and pectin based on basic recipes № 95 and № 126 are listed in Table 1 .

The experimental samples preparation of the marshmallow was carried out according to the traditional technology of the white-pink marshmallow according to the classic recipe Table 1.

Table 1

Formulations of white-pink marshmallow on agar and pecti (control) and with different mass fraction of "Magnetofood" food additive (Experimenal)

\begin{tabular}{|l|c|c|c|c|c|c|c|c|}
\hline \multirow{2}{*}{$\begin{array}{l}\text { Name of the raw } \\
\text { materials }\end{array}$} & \multicolumn{6}{|l|}{ Inputs of the raw material per 1 ton of finished product, kg } \\
\cline { 2 - 10 } & \multicolumn{6}{|l|}{$\begin{array}{l}\text { marshmallow samples on agar } \\
\text { pectin }\end{array}$} \\
\cline { 2 - 10 } & $\begin{array}{l}\text { № 1 } \\
\text { Control }\end{array}$ & № 2 & № 3 & № 4 & $\begin{array}{l}\text { № 5 } \\
\text { Control }\end{array}$ & № 6 & № 7 & № 8 \\
\hline Granulated sugar & 673,0 & 672,0 & 671,5 & 671,0 & 671,0 & 670,0 & 670,5 & 669,0 \\
\hline Powdered sugar & 29,9 & 29,9 & 29,9 & 29,9 & 29,9 & 29,9 & 29,9 & 29,9 \\
\hline Molasses & 139,4 & 139,4 & 139,4 & 139,4 & 142,9 & 142,9 & 142,9 & 142,9 \\
\hline Apple sauce & 390,0 & 390,0 & 390,0 & 390,0 & 298,0 & 298,0 & 298,0 & 298,0 \\
\hline Egg white & 65,0 & 65,0 & 65,0 & 65,0 & 65,0 & 65,0 & 65,0 & 65,0 \\
\hline Agar & 8,6 & 8,6 & 8,6 & 8,6 & - & - & - & - \\
\hline Apple pectin & - & - & - & - & 13,4 & 13,4 & 13,4 & 13,4 \\
\hline lactic acid & 11,8 & 11,8 & 11,8 & 11,8 & 8,4 & 8,4 & 8,4 & 8,4 \\
\hline Sodium lactate & - & - & - & - & 6,8 & 6,8 & 6,8 & 6,8 \\
\hline $\begin{array}{l}\text { Different kinds } \\
\text { of essence }\end{array}$ & 2,0 & 2,0 & 2,0 & 2,0 & 2,0 & 2,0 & 2,0 & 2,0 \\
\hline Colouring agent & 0,6 & 0,6 & 0,6 & 0,6 & 0,6 & 0,6 & 0,6 & 0,6 \\
\hline $\begin{array}{l}\text { "Magnetofood" } \\
\text { food additive }\end{array}$ & - & 1,0 & 1,5 & 2,0 & - & 1,0 & 1,5 & 2,0 \\
\hline
\end{tabular}

The data on the influence of "Magnetofood" food additive on the basic physicochemical and technological parameters of the experimental samples of the white-pink marshmallow are presented in Table 2. 
Resource and Energy Saving Technologies of Production and Packing of Food Products as the Main Fundamentals of Their Competitiveness: Proceedings of the 7th International Specialized Scientific and Practical Conference, September 13, 2018. Kyiv, Ukraine

Table 2

The influence of the "Magnetofood" food additive on the physico-chemical and technological indicators of the experimental samples of white - pink marshmallow on agar and pectin

\begin{tabular}{|l|l|l|l|l|l|l|l|l|}
\hline \multicolumn{1}{|c|}{$\begin{array}{c}\text { Quality } \\
\text { indicators }\end{array}$} & $\begin{array}{c}\text { Sample } \\
1\end{array}$ & $\begin{array}{c}\text { Sample } \\
2\end{array}$ & $\begin{array}{c}\text { Sample } \\
3\end{array}$ & $\begin{array}{c}\text { Sample } \\
4\end{array}$ & $\begin{array}{c}\text { Sample } \\
5\end{array}$ & $\begin{array}{c}\text { Sample } \\
6\end{array}$ & $\begin{array}{c}\text { Sample } \\
7\end{array}$ & $\begin{array}{c}\text { Sample } \\
8\end{array}$ \\
\hline $\begin{array}{l}\text { Mass } \\
\text { fraction of } \\
\text { moisture, } \\
\%\end{array}$ & $17 \pm 0,3$ & $17,3 \pm 0,3$ & $17,4 \pm 0,3$ & $17,5 \pm 0,3$ & $17 \pm 0,3$ & $17,4 \pm 0,3$ & $17,5 \pm 0,3$ & $17,6 \pm 0,3$ \\
\hline $\begin{array}{l}\text { Total } \\
\text { acidity, } \\
\text { deg. }\end{array}$ & $0,7 \pm 0,02$ & $0,6 \pm 0,02$ & $0,5 \pm 0,02$ & $0,5 \pm 0,02$ & $5,90 \pm 0,2$ & $5,4 \pm 0,2$ & $5,30 \pm 0,2$ & $5,2 \pm 0,2$ \\
\hline $\begin{array}{l}\text { Density, } \\
\text { kg / } \\
\text { m } \text { (the } \\
\text { smallest } \\
\text { value) }\end{array}$ & $545 \pm 2$ & $490 \pm 2$ & $485 \pm 2$ & $484 \pm 2$ & $550 \pm 2$ & $485 \pm 2$ & $480 \pm 2$ & $479 \pm 2$ \\
\hline $\begin{array}{l}* \text { Duration } \\
\text { of } \\
\text { whipping, } \\
\text { min. }\end{array}$ & 16 & 14 & 14 & 14 & 10 & 8 & 8 & \\
\hline $\begin{array}{l}\text { Plastic } \\
\text { strength } \\
\text { KPa }\end{array}$ & $9,0 \pm 0,5$ & $10,3 \pm 0,5$ & $10,8 \pm 0,5$ & $10,9 \pm 0,5$ & $6,5 \pm 0,5$ & $7,0 \pm 0,5$ & $7,4 \pm 0,5$ & $7,5 \pm 0,5$ \\
\hline
\end{tabular}

*Duration of whipping, min - the time to achieve the lowest density value pf the experimental samples of the marshmallows mass.

\section{Conclusion}

From the experimental data Table 2 it follows that the introduction of "Magnetofood" food additive in the amount of $(0,10-0,20) \%$ of the prescription composition contributes to the improvement of physico-chemical and technological indicators of the experimental samples of white-pink marshmallow on agar and pectin:

- the mass fraction of moisture is increased by $(1,7-2,9) \%$ in the samples on agar and $(2,3-3,5) \%$ in the samples on pectin due to water binding and water-containing capacity of the "Magnetofood" additive;

- decreases the acidity of $(0,1-0,2)^{0}$ in the samples on agar and on $(0,5-0,7)^{\circ}$ in the samples on pectin due to the amphoteric nature of "Magnetofood" additive;

- the density value decreases, in particular the smallest value, by (55-61) $\mathrm{kg} / \mathrm{m}^{3}$ for agar, by $(65-71) \mathrm{kg} / \mathrm{m}^{3}$ for pectin and the duration of whipping during 2 minutes. This can be explained as follows: "Magnetofood" surface-active nanoparticles with the complexing and structure-forming properties contribute to 
branching of the main chains of egg white macromolecules in a dispersion medium, slowing down the process of the loss of liquid and thinning the walls of the air bubbles, with the result that in a decrease in the density of the experimental samples of the whipping masses is decreasing in comparison with the control samples.

- the plastic strength increases by $(1,3-1,9) \mathrm{kPa}$ in the samples on agar and $(0,5$ $1,0) \mathrm{kPa}$ in the samples on pectin due to the structure-forming and stabilizing effect of the nanoparticles "Magnetofood" additive which contributes to gel-forming capacities of pectin and agar which allows to increase the viscosity in the Gibbs-Plateau channels, slow down the weeping process and stabilize the gel framework of the foamy structure.

It should be noted that the best results were obtained with the content of the "Magnetofood" additive $0,15 \%$ by weight of the raw materials.

Conducted researches allowed to scientifically substantiate the recipe (Table 1) and the technological parameters of the production of the white-pink marshmallow. Fig. 1 shows the technological scheme of the white-pink marshmallow on agar with the addition of "Magnetofood" food additive. A distinctive feature of the new technology is the blending mixing of "Magnetofood" food additive with the gelling agents which are used before the technological operation ofsteeping with the gelling agents in the cold water. The production technology of the white-pink marshmallow on pectin with the addition of "Magnetofood" food additive includes the same stages but has some differences in the technological regimes.

The technological process of the white pink marshmallows production involves the following stages: the selection and preparation of the prescription components the bulk components are sifted, essence, lactic acid, colouring agent, egg white are dissolved, glucose syrup is heated and filtered; the obtained dry mixture by gelling agents with "Magnetofood" food additive, followed by soaking and swelling in the cold water at the temperature of $(20 \pm 2)^{\circ} \mathrm{C}$ for $(2,5-3,0) \cdot 3600 \mathrm{~s}-$ for agar.

Swelling of the pectin-magnetofood mixture is added to the apple sauce (premixed with sugar in an amount equal to the amount of pectin) for $(4,0-8,0) \cdot 3600 \mathrm{~s}$ at $(20 \pm 2){ }^{\circ} \mathrm{C}$ and thoroughly mixing for the good distribution and pectin swelling. It should be noted that at the stage of soaking and swelling, the solvation of "Magnetofood" food additive is and swelling of thegelling agents with its partial structuring under the nanoparticles action of "Magnetofood" additive which facilitating the water ingress into the most organized sections of the gelling agents chain.

Next, the solution of agar mixture with "Magnetofood" additive is heated to the temperature of (95-100) ${ }^{\circ} \mathrm{C}$ and held for (10-15) $60 \mathrm{~s}$. Then add the sugar and mix thoroughly at the temperature $(95-98){ }^{\circ} \mathrm{C}$ for $(20-30) \cdot 60 \mathrm{~s}$ and a solids content of $\mathrm{DS}=(84,5 \pm 0,5) \%$. Get agar-sugar syrup. At this stage, "Magnetofood" additive increases of the agar solubility due to its water-holding capacity and the interaction of its ionized nanoparticles with polarized agar groups which lead to branching of the molecules main chains of the gel components which contributes to their chain and better penetration of the water molecules. A pectin-apple-magnetofood mixture is wiped through a sieve with a hole diameter $\mathrm{d}=0,8 \cdot 10^{-3} \mathrm{~m}$ and sent for the whipping 
(which depending on the acidity of the puree used, make sodium lactate) with the prepared egg white. The duration of whipping (4-6)·60 s. Get protein-pectin-apple mixture with "Magnetofood" addition.

The cooking of agar-sugar-dextrose syrup with "Magnetofood"food additive. In the agar-sugar-magnetofood syrup is added the prepared molasses and mixed at (95$100){ }^{\circ} \mathrm{C}$ for $(8-10) \cdot 60 \mathrm{~s}$. In the case of the marshmallow preparation on pectin the sugardextrose syrup is prepared by boiling sugar with glucose syrup at a temperature of $(105-110){ }^{\circ} \mathrm{C}$ until the solids content is DS $=(82,5 \pm 2) \%$.

The cooking of the whipped protein-apple mass. The apple puree with sugar and half an egg white (in the form of a solution) are whipped for (5-8).60 s at a temperature $(20 \pm 2){ }^{\circ} \mathrm{C}$. Then add the second half of the egg whites by continuing to whip another $(5-8) \cdot 60 \mathrm{~s}$.

The cooking marshmallow mass. To the agar-sugar-syrup with "Magnetofood" food additive add a whipped protein-apple mass, taste and aromatic emulsion, and the mixture is kneaded on a slow stirrer at a temperature of $(54 \pm 1){ }^{\circ} \mathrm{C}$ for $(3-4) \cdot 60$ s with for the same distribution of the gel and flavoring substances in the whipped mass. For marshmallow on pectin, the process is identical.

Formation, structure formation and drying. The molded products are sent for holding. The duration of structure formation and drying (6-8)·3600 $\mathrm{s}$ at a temperature $(35-40){ }^{\circ} \mathrm{C}$

Packing, packaging, labeling and storage. The ready marshmallows are packed and stored in the storage conditions at a relative humidity of $(75 \pm 2) \%$. 
Resource and Energy Saving Technologies of Production and Packing of Food Products as the Main Fundamentals of Their Competitiveness: Proceedings of the 7th International Specialized Scientific and Practical Conference, September 13, 2018. Kyiv, Ukraine

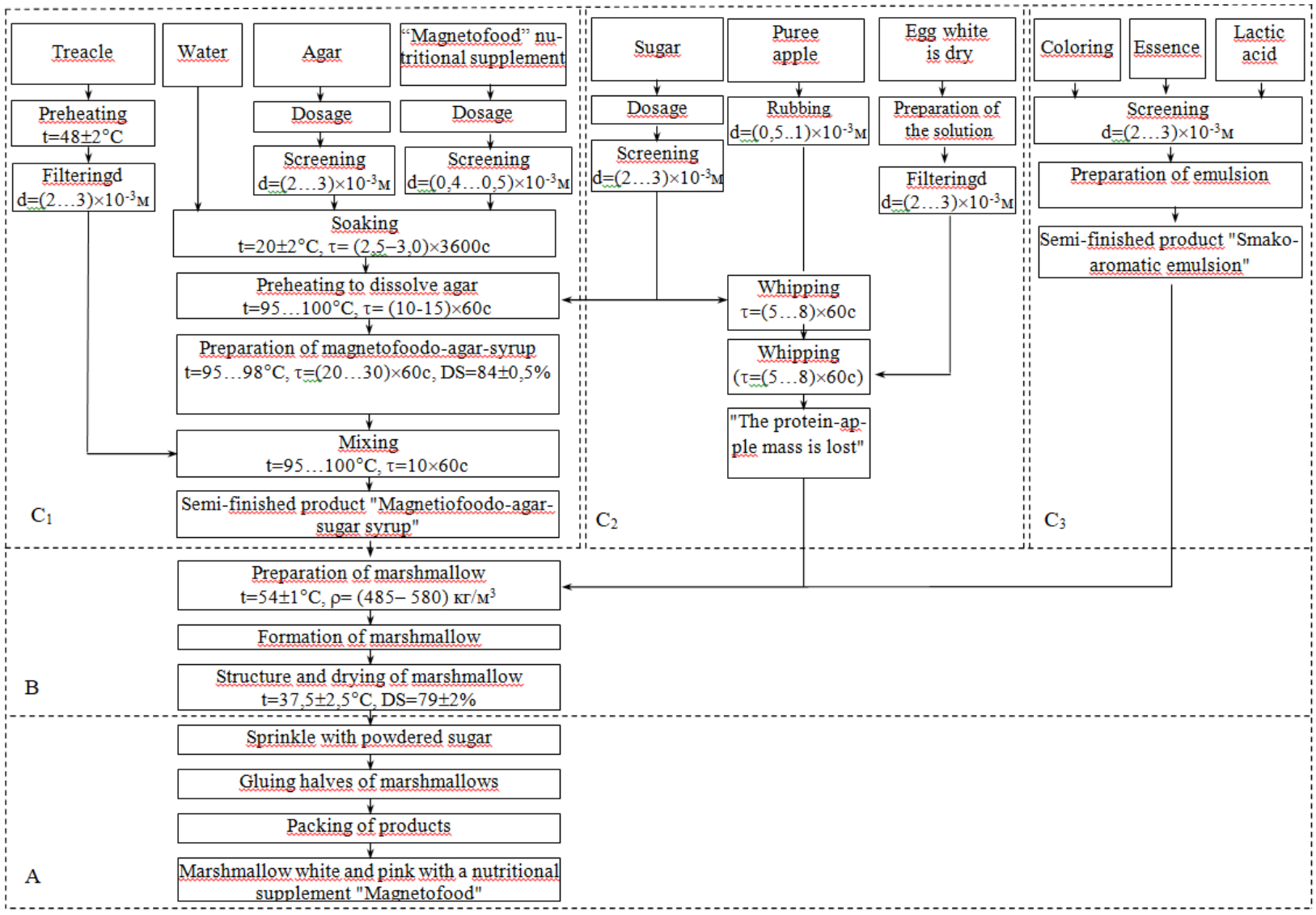

Figure 1. The technological scheme of white-pink marshmallows on agar with "Magnetofood" food additive: $\mathrm{A}, \mathrm{B}, \mathrm{C}_{1}, \mathrm{C}_{2}, \mathrm{C}_{3}$ are the subsystem of the technological scheme of the marshmallows production

\section{References}

1. Tsykhanovska IV., Aleksandrov OV.,Gontar TB., Barsova ZV., Kokodiy MG. Investigation of magnetite nanoparticles of lipid-magnetite suspensions by methods of photometry and electron microscopy. East European Journal of Advanced Technologies. 2016; 6/3 (81): 28 - 38. doi: 10.15587/17294061.2016.69826

2. Ilyukha NG., Tsykhanovska IV., Barsova ZV., Kovalenko VA. Production technology and quality indices of a food additive based on magnetite. East European Journal of Advanced Technologies, 2010; 6, (48): 32 - 35.

3. Tsykhanovska IV., Aleksandrov OV., Evlash VV., Lazareva TA., Svidlo KV., Gontar TB. Development of technology of rye-wheat bread "Kharkiv Rodnichok" with the addition of a multifunctional nutritional supplement "Magnetofood". East European Journal of Advanced Technologies. 2017; 6/11 (90): 48 - 58 .

4. Tsykhanovska I., Alexandrov A., Evlash V., Lazareva T. Bryzytska O. Substantiation of the interaction mechanism between the lipo- and glucoproteids 
Resource and Energy Saving Technologies of Production and Packing of Food Products as the Main Fundamentals of Their Competitiveness: Proceedings of the 7th International Specialized Scientific and Practical Conference, September 13, 2018. Kyiv, Ukraine

of rye-wheat flour and nanoparticles of the food additive "Magnetofood". East European Journal of Advanced Technologies. 2018; 4 /11 (94); 61-68. doi: 10.15587/1729-4061.2018.140048.

5. Helena Bovšková and Kamila Míková. Factors Influencing Egg White Foam Quality // Czech J. Food Sci. Vol. 29, 2011, No. 4: 322-327.

6. Fioramonti S. A. [et al.] Design and characterization of soluble biopolymer complexes produced by electrostatic self-assembly of a whey protein isolate and sodium alginate // Food Hydrocolloids, 2013. Vol.05. P. 1-8.

7. Mao L. [et al.] Evaluation of volatile characteristics in whey protein isolateepectin mixed layer emulsions under different environmental conditions // Food Hydrocolloids, 2014. Vol. 41. P. 79-85. 